\title{
From Cob to Can: \\ The Development of Iowa's Canning Industry in the Late Nineteenth and Early Twentieth Centuries
}

\section{DEREK ODEN}

A LOCAL GROCER, advertising in the Vinton Eagle in July 1885, suggested one benefit of canned goods. "Why Cook in Hot Weather?," the ad asked. It listed the variety of canned goods the store featured, including canned mackerel, lobsters, and other kinds of seafood. 'Before the development of canning, none of these items would have been available to land-locked midwesterners. By 1901, Walter Eliott, an official for the Knoxville, Iowa, cannery, could claim that "the tastes and desires of humanity have so multiplied and have become so refined that the crude, meager means and methods of a generation ago, will not suffice." He went on to describe a host of improvements that had raised the standard of living, including the presence of pianos in homes, gold watches in pockets, and more comfortable carriages. People should also have "greater variety of choicest foods," he stated. "All classes of people crave this, and there is nothing wrong about it. ... This is what brought about the canning industry." ${ }^{2}$

Like the local grocer and the cannery official who praised the advantages of increased food options provided by new developments in canning technology, most small-town Iowans were generally enthusiastic about technological progress, the

1. Vinton Eagle, $7 / 31 / 1885$.

2. Walter Eliott, "The Canning Industry," in Iowa Department of Agriculture, Iowa Year Book of Agriculture [for 1900], 18 (hereafter cited as Year Book).

THE ANNALS OF IOWA 63 (Fall 2004). (C) The State Historical Society of Iowa, 2004. 
emerging integration of the nation's marketplace, and the expanding selection of consumer products available to them. ${ }^{3}$ With the integration of the nation's marketplace, Iowans could more easily purchase non-local foods and other consumer products. As historian William Cronon described it so vividly, "The Iowa farm family who raised corn for cattle purchase from Wyoming and who lived in a farmhouse made of Wisconsin pine clothed themselves with Mississippi cotton that Massachusetts factory workers had woven into fabric, worked their fields with a plow manufactured in Illinois from steel produced in Pennsylvania, and ended their Sunday meal by drinking Venezuelan coffee after enjoying an apple pie made on an Ohio stove from the fruit of a backyard orchard mixed with sugar from Cuba and cinnamon from Ceylon." ${ }^{\prime 4}$ Iowans, in turn, could

3. During the late nineteenth and early twentieth centuries, Americans generally embraced new technologies, believing that they would usher in a better life for all classes of society. For an overview of the history of American technology, see Alan I Marcus and Howard P. Segal, Technology in America: A Brief History (New York, 1989). Howard P. Segal, Technological Utopianism in American Culture (Chicago, 1985), is a useful discussion of this technological optimism. A number of books reveal technological hopefulness across a wide range of innovations: Joseph J. Corn, ed., Imagining Tomorrow: History, Technology, and the American Future (Cambridge, MA, 1986); Joseph J. Corn, The Winged Gospel: America's Romance with Aviation, 1900-1950 (1983; reprint, Baltimore, 2002); and David E. Nye, Electrifying America: Social Meanings of a New Technology, 1880 1940 (Cambridge, MA, 1990). Katherine Jellison, Entitled to Power: Farm Women and Technology, 1913-1963 (Chapel Hill, NC, 1993); and Hal S. Barron, Mixed Harvest: The Second Great Transformation in the Rural North, 1870-1930 (Chapel Hill, NC, 1997), among others, suggest that rural Americans were more ambivalent about technological innovations. A large number of articles embracing the potential of canned food to revolutionize the American diet can be found throughout The Canned Goods Trade, a national trade journal for canning published throughout the period, beginning in 1876. Industry leaders claimed that canning technology was improving inferior methods of food preparation, incorporating the latest scientific research, and providing affordable food to all classes of people. For an excellent example, see Hugh S. Orem, "A Revolution in the Kitchen," The Canned Goods Trade, 9/30/1910, 18-24.

4. William Cronon Nature's Metropolis: Chicago and the Great West (New York, 1991), 310. Scholars have long investigated the development of a national marketplace and its many economic, social, and environmental implications. Writers such as Don Martindale and R. Galen Hanson, in Small Town and the Nation: The Conflict of Local and Translocal Forces (Westport, CT, 1969), have emphasized that the development of "continent-wide markets" (xiv) contributed to ending the previous isolation of small communities. More recently, historians have investigated the environmental impact and cultural meanings of re- 
more effectively market their own products to the entire nation, presenting business opportunities and widening their perception of the state's economic potential. Sioux City's Corn Palace, Creston's Blue Grass Palace, and Ottumwa's Coal Palace were vivid visual reminders of Iowa's successes in developing the state's natural endowments. $^{5}$

Iowa's farmers, town leaders, and local entrepreneurs continually sought ways to marshal their resources effectively to achieve prosperity, since residents of other states could also more easily market their products. Thomas Morain, in his investigation of Jefferson, Iowa, stressed the railroad's importance in facilitating this increased commercial competition by sharply lowering the cost of freight transportation. "Goods produced cheaply in eastern factories could undersell local manufacturers, spelling the doom of many local craftsmen and industries." And, indeed, Jefferson's business directories note the reduced economic vitality of its small-town industries. There, and throughout the region, national brand-name crackers, clothing, and flour eventually replaced products produced by local manufacturers. ${ }^{6}$

In this competitive environment, small-town leaders tried various strategies to take advantage of local resources. Some industries, such as agricultural equipment manufacturing, survive to the present day; others, such as coal mining, experienced both

source use, revealing that as the "complexity of economic networks" increased, Americans' perception of commodities became increasingly dissociated from their origins. See, for example, Jennifer Price, Flight Maps: Adventures with $\mathrm{Na}$ ture in Modern America (New York, 1999) 7, 21, 54; and Cronon, Nature's Metropolis, 310-40. Cronon provides an in-depth discussion of the complex relationship between city and countryside. He investigates how Chicago's vast hinterland provided such resources as coal and livestock, while the city's factories produced reapers, factory-made clothing, and a variety of other products for rural consumers.

5. Thomas J. Morain, Prairie Grass Roots: An Iowa Small Town in the Early Twentieth Century (Ames, 1988), 32.

6. Ibid., 27; Lewis Atherton, Main Street on the Middle Border (Chicago, 1954), 225-27. For a brief discussion of the growth of the state's railroad network, see Dorothy Schwieder, Iowa: The Middle Land (Ames, 1996), 53, 63, 65. Iowa ranked in the top ten among all states in regards to total track miles by the turn of the century (63). Timothy Mahoney, River Towns in the Great West: The Structure of Provincial Urbanization in the American Midwest, 1820-1870 (New York, 1990), provides a more detailed account of the effect of greater commercial competition in midwestern river towns brought about by the railroad. 
a rapid rise and a quick downfall. The state's industrial history reveals much about Iowans' cultural assumptions and the nature of its economy. Scholars have investigated other agricultural industries, such as agricultural implement manufacturing and meatpacking. ${ }^{8}$ And Dorothy Schwieder's investigation of the state's mining industry showed how that industry contributed to the state's cultural diversity, as well as provided shortlived economic prosperity to many Iowa towns. ${ }^{9}$ Yet scholars have generally neglected canning and other industries closely associated with farming, even on a national level. ${ }^{10}$

This oversight is surprising because canning provided a lucrative market for produce while serving as a significant source of employment. The industry grew rapidly, increasing production from four million cases in 1870 to 206 million cases by 1937.

7. For an overview of Iowa's early industrial development, see Keach Johnson, "Iowa's Industrial Roots, 1890-1910," Annals of Iowa 44 (1978), 163-90; and idem, "Iowa's Industrial Roots: Some Social and Political Problems," ibid., 247-77.

8. Mark R. Finlay, "System and Sales in the Heartland: A Manufacturing and Marketing History of the Hart-Parr Company, 1901-1929," Annals of Iowa 57 (1998), 337-73, investigated the management decisions, manufacturing methods, and industry consolidation contributing to the decline of what had once been one of the nation's largest tractor manufacturers. Iowa's meatpacking industry has received considerable attention. See, for example, Wilson J. Warren, "Evangelical Paternalism and Divided Workers: The Nonunion Era at John Morrell and Company in Ottumwa, 1877-1917," Annals of Iowa 56 (1997), 32148; idem, "The Welfare Capitalism of John Morrell and Company, 1922-1937," Annals of Iowa 47 (1984), 497-517; idem, "The Heyday of the CIO in Iowa: Ottumwa's Meatpacking Workers, 1937-1954," Annals of Iowa 51 (1992), 363-89. Deborah Fink has addressed recent aspects of the industry in lowa in Cutting into the Meatpacking Line: Workers and Change in The Rural Midwest (Chapel Hill, NC, 1998).

\section{Schwieder, Iowa: The Middle Land, 242.}

10. Most of the pertinent works are aged trade histories that are useful for identifying important canning pioneers and crucial technological innovations, but they lack historical interpretation. For instance, James H. Collins, The Story of Canned Foods (New York, 1924), and Earl Chapin May, The Canning Clan: A Pageant of Pioneering Americans (New York, 1937) overemphasize technological and corporate achievements with little discussion of the topic's other dimensions. A few relatively recent dissertations and monographs provide a scholarly approach. See, for example, Edward F. Keuchel, "The Development of the Canning Industry in New York State to 1960" (Ph.D. diss., Cornell University, 1970); and Vicki L. Ruiz, Cannery Women, Cannery Lives: Mexican Women, Unionization, and the California Food Processing Industry, 1930-1950 (Albuquerque, NM, 1987). 
By the middle of the twentieth century, much of the nation's tomato, beet, sweet corn, pea, and asparagus harvest was canned, along with large amounts of the nation's fruit and juice, and the industry employed up to 500,000 individuals during peak hiring times. ${ }^{11}$ The canning industry appeared in Iowa as a part of the state's rapid growth in transportation, industrialization, population, and technological expertise. It began in Iowa in the late 1870s and grew steadily over the following decades; by 1923, fifty-two canneries were dispersed unevenly across the state. In seven out of ten years between 1914 and 1924, Iowa led the nation in sweet corn canning. ${ }^{12}$

Iowa's soil and climate were ideal for the development of a vibrant corn canning industry. Farmers quickly discovered that corn grew especially well in the state's rich soil during its hot, humid summers. They also embraced the practice of fattening their livestock on the state's plentiful field corn harvests. As a result of Iowa farmers' enthusiasm for corn production, by the 1880 s, Iowa had outstripped Illinois as the nation's leading corn producer. ${ }^{13}$ The development of a corn canning industry in Iowa provided an alternative use for an abundant Iowa commodity. Its emergence represents an early step in a continuing adaptive process that has not only produced canned corn but also created a diverse array of other uses for corn, such as corn sweeteners for a multitude of food products, starch for plastics, and ethanol for auto fuel. ${ }^{14}$

11. The Canning Industry: Its History, Importance, Organization, Methods and the Public Service Values of Its Products, 2nd ed. (Washington, DC, 1954), 7, 10.

12. Iowa Bureau of Labor Statistics, Directory of Manufacturing Establishments [for 1925], 7, 10. A sampling of cannery locations taken from that directory and from the bureau's biennial reports for 1884-85, 1895-96, and 1910-11 reveals that canneries were widely dispersed. However, some regions attracted more canneries. For instance, the eastern section of the state had more canneries than the western region. This pattern does not necessarily appear to be related to soil or climate conditions since both topographical and weather variations occur from north to south as well as east to west. For a brief discussion of Iowa's soil and climate, see Leland Sage, A History of Iowa (Ames, 1974), 3-15.

13. John C. Hudson, Making the Corn Belt: A Geographical History of MiddleWestern Agriculture (Bloomington, IN, 1994), 9; and Schwieder, Iowa: The Middle Land, 134.

14. The growth of the corn refining industry is discussed in the 1989 and 1990 Corn Annual and in Hudson, Making the Corn Belt, 193-96. 
Iowans welcomed the canning industry's entrance into the state and viewed its presence as an economic asset to their communities. Canneries infused additional money into local economies and offered supplemental income for farmers and opportunities for women to provide for their families. They also demonstrated the unequal financial opportunities that characterized the period's economic system; white males generally started the businesses, but most of the low-paying positions were filled by women and underage workers.

THE CANNING INDUSTRY first emerged in Europe, but it developed more fully in the United States. ${ }^{15}$ In 1819 the Englishman William Underwood established one of the first canning plants in the United States. His small Massachusetts facility processed a variety of products, including cucumbers, fruits, and condiments, some of which were canned. By the 1840 s, canning entrepreneurs had opened operations in Maine, Maryland, and Pennsylvania. The next decade witnessed the establishment of canning factories in New York and Delaware. The military's demands for preserved foods during the Civil War dramatically increased the consumption of canned goods. During the 1870s, canning spread throughout the Midwest and into California. Between 1870 and 1900, the industry grew dramatically in the United States, from a mere 100 canneries in 1870 to 1,800 by 1900 . Canned products reflected their geographical location: Alaskan canners processed salmon; Wisconsin dominated pea processing; and sweet corn rose to prominence in other parts of the Midwest. The United States emerged as the world's leader in canning due to its excellent transportation network, sizable food surpluses, and large domestic market. ${ }^{16}$

15. The food preservation methods that led to the canning industry originated during the Napoleonic Wars, when the French government offered a reward of 1,200 francs for an improved food preservation technique. After 15 years of struggle, Nicolas Appert, a cook and inventor, revealed a superior food preservation method: placing food in airtight containers and cooking it at high temperatures for prolonged periods of time. In 1810 Appert summarized his research in The Art of Preserving All Kinds of Animal and Vegetable Substances (London, 1812). His method soon spread to England, where Peter Durand began using tin cans instead of glass bottles. The Canning Industry, 4.

16. The Canning Industry, 6; Keuchel, "Canning Industry," 20. 
The rise of the U.S. canning industry was also due to continuous improvement in both methods and technology in every stage of the canning process, from preparing the raw materials to ensuring preservation. Although improvements were diverse, and machinery often became specialized to suit particular animal or plant products, some inventions were useful for all sorts of canning. In 1861 canners realized that adding calcium chloride to water increased water temperature, which resulted in reduced boiling time. In $1874 \mathrm{~A}$. K. Shriver, a Baltimore inventor, created the pressure or retort cooker, which further standardized canning temperatures. During the following decades, canning became increasingly mechanized, as new innovations eliminated waste and improved the efficiency and safety of the process, thus lowering costs. For instance, corn canners adopted mechanical devices to husk the ears, remove other non-edible matter, and automatically remove the kernels. ${ }^{17}$

The emergence of a vibrant canning industry in Iowa fits into the overall nature of the state's early economic development, in which agricultural industries were most prominent. ${ }^{18}$ During the late nineteenth century, Iowa's leading industries included cheese making, meatpacking, oat processing, and agricultural implement manufacturing, all of which reflected agriculture's predominance. By 1900, the state ranked third in cheese, butter, and condensed milk production. In the closing years of the nineteenth century, Iowa's smaller urban areas, as well as its larger cities, witnessed significant manufacturing growth, and companies were usually relatively small. ${ }^{19}$

Small towns such as Atlantic, Iowa, in Cass County, processed the raw animal and crop resources of their hinterlands as early as the 1870 s and 1880 s. By 1879 , the town's meatpacking plant had processed 29,000 hogs. In addition to this facility, the town had four flour mills and a brewery and was anticipating the arrival of its own vegetable canning facility. By 1884, the town had added a creamery. By the end of the 1880 s, the town

17. The Canning Industry, 6.

18. Schwieder, Iowa: The Middle Land, 232; Johnson, "Iowa's Industrial Roots."

19. Twelfth Census of the United States, 1900. Report on Manufacturers, Part 1, clxxix, Part 2, 237. 


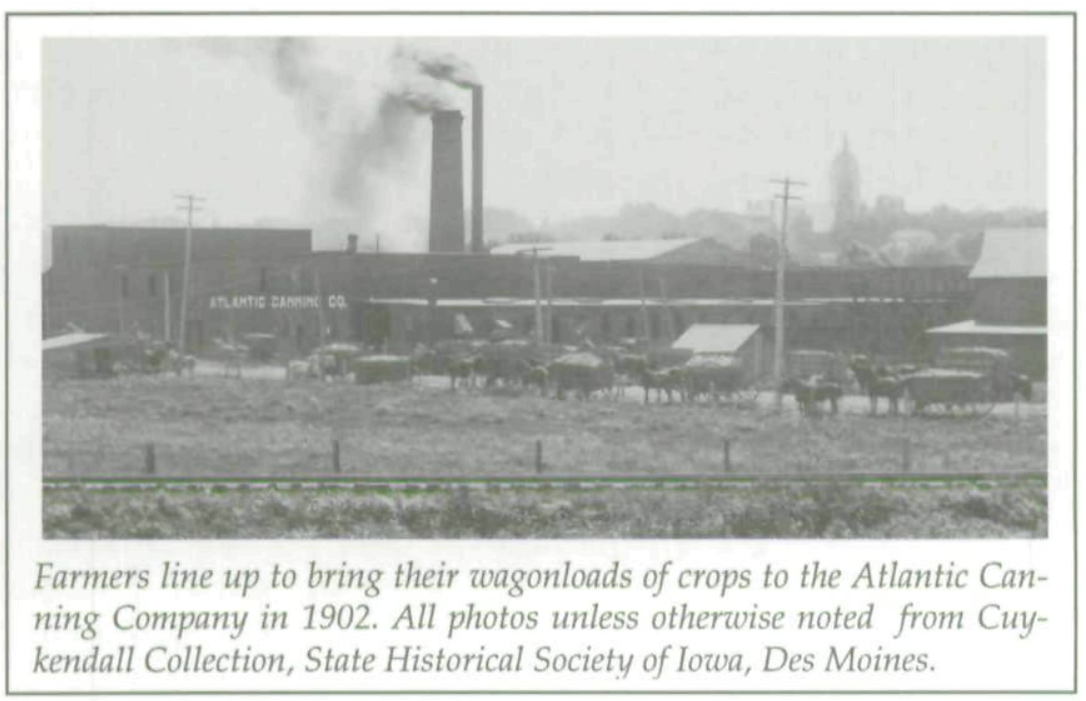

had developed poultry raising facilities. ${ }^{20}$ Atlantic was typical in its enthusiasm for developing agricultural industries devoted to processing or marketing local raw materials.

TOWN AND STATE BOOSTERS eagerly sought to establish factories to process agricultural products. The secretary of the Montgomery County Agricultural Society stated that his town needed "glucose and vinegar works, distilleries, canning factories, packing houses and starch factories, etc." In 1884 P. P. Kelly of the Mills County Agricultural Society wrote that the area needed factories that could process farmers' raw materials and supply them with agricultural equipment. In 1887 the secretary of the State Agricultural Society, John Shaffer, insisted, "Our beef and pork should all be cured within our own borders. . . . Here should be made the starch and sugar from our corn. Here should be canned the fruits and vegetables to supply less favored sections." Similar comments stressing the need for agriculturally related factories and reflecting the desire to promote local economic growth can be found throughout the historical record of Iowa's small towns during the late nineteenth century. ${ }^{21}$

20. Iowa State Agricultural Society, Report to the Governor [for 1879], 353; ibid., 1884, 350; ibid., 1888, 295 (hereafter cited as ISAS, Report).

21. ISAS, Report, 1883, 539; ibid., 1884, 558; ibid., 1887, 11. 
To attract manufacturing facilities, town boosters cited their town's various advantages, such as railroad access or proximity to coal reserves, water power, or raw materials. In $1879 \mathrm{~J}$. Sexton Kelso of Union County claimed that "with ample water-power, and cheap fuel from our coal fields, nothing is needed but capital and enterprise to develop rich industries." In the next few years, boosters in Benton and Montgomery County also cited the possibilities of using their area's rivers for water power. Unfortunately, this benefit probably did little to lure manufacturing facilities; in 1890, of 15 Iowa canneries that reported their power source, none listed water power. ${ }^{22}$

Although not every community acquired a vegetable cannery, many expressed the desire for one and stressed the possible benefits. This desire persisted throughout the period up into the early years of the twentieth century. For instance, in 1903, at least 40 towns sought canneries. Town officials stressed benefits to the communities, such as the possibilities of marketing surplus vegetables, diversifying farm operations, and adding jobs. In 1883 Joel Lihtner of Johnson County indicated that a cannery might decrease the consumption of canned products from other regions and stimulate local vegetable raising. E. M. Brink of Cedar County stated that his town needed a facility because "each year hundreds of dollars worth of vegetables, for which there is no market, rot in the gardens." Hardin County's M. W. Moir believed that a cannery would increase crop diversity by providing a market for additional crops. In 1881 a writer for the State Agricultural Society proclaimed the benefits of establishing a canning industry, noting that the markets for canned goods were almost limitless and included the American West and Europe. The author also envisioned the possibility of canning a host of foodstuffs, including meats, vegetables, and fruits. This would prove to be an overly optimistic prediction in regard to

22. ISAS, Report, 1879, 516; ibid., 1881, 336; ibid., 1882, 411 and 367; Eleventh Census of the United States: 1890. Report on Manufacturing Industries, Part 1, 942. According to William Cronon, in Nature's Metropolis, 34-35, nineteenth-century boosters, whose "rhetoric always inclined toward enthusiastic exaggeration and self-interested promotion," "believed that climate, soils, vegetation, transportation routes and other features of the landscape all pointed toward key locations that nature had designated for urban greatness." 


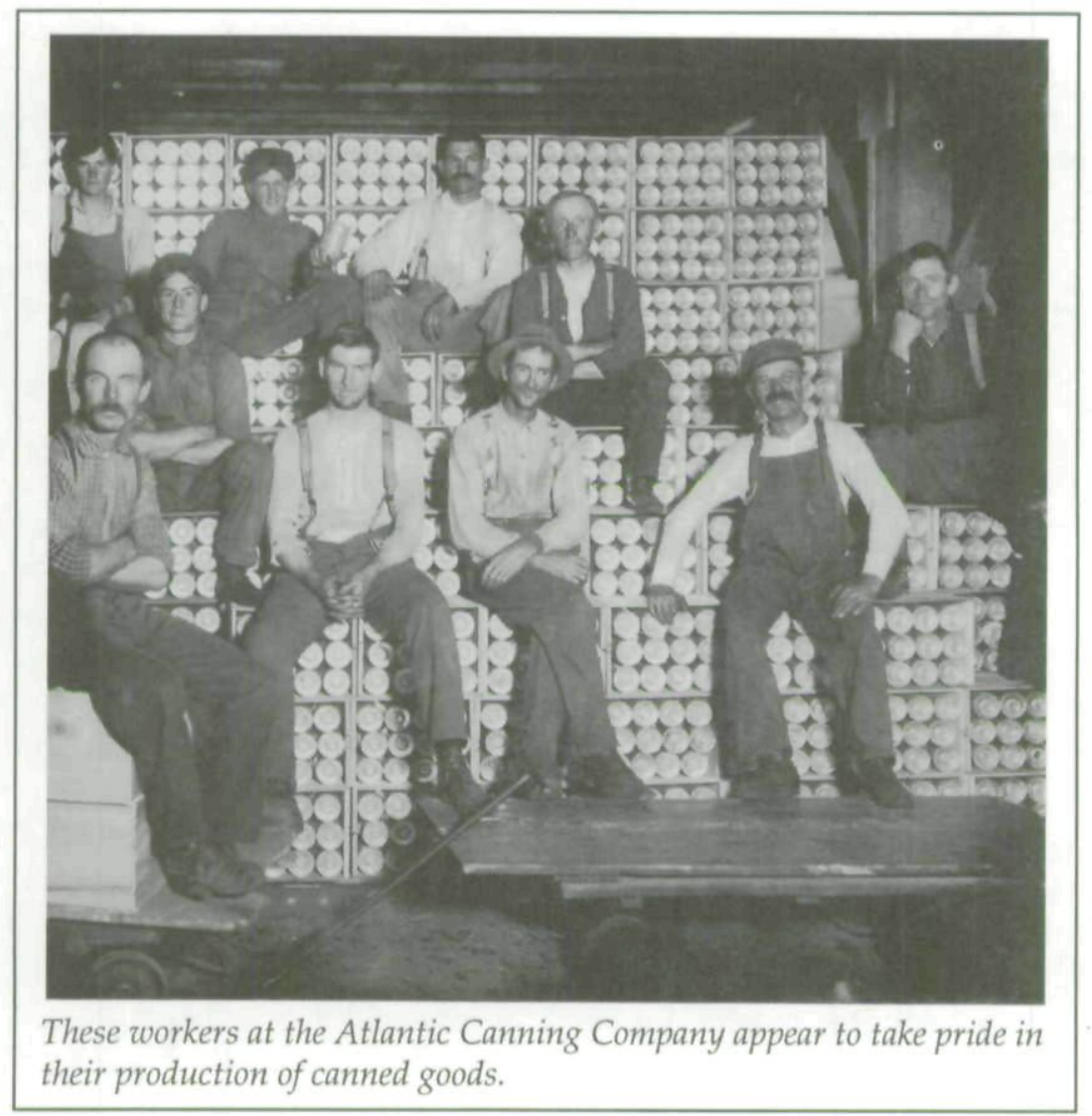

both the extent of Iowa's potential market and the diversity of Iowa canned goods. ${ }^{23}$

23. Marcia Chinitz Goldberg and Phillip Goldberg, "Atlantic's Canning Season of 1902," Palimpsest 76 (1995), 101; ISAS, Report, 1883, 478; ibid., 1884, 353; ibid., 1883,445 ; ibid., 1881, 30. A large portion of the state's canned goods during the period were consumed within Iowa or surrounding states. As transportation improved, other regions, such as the American Southwest, became lucrative markets. The Iowa Canning Company of Vinton was one of the state's most successful facilities, shipping large amounts of canned goods to southern and western states, especially California and Texas. See Robert Norman Ford, "The Vegetable Canning Industry in Iowa" (master's thesis, University of Chicago, 1948), 10-12. For a more detailed discussion of the nature of the market for sweet corn as it had developed by mid-century, see Richard A. Andrews, Minnesota Experiment Station, A Study of the Sweet Corn Industry in the Midwest Farm Economy, Technical Bulletin 232 (St. Paul, 1959), 72-83. Sweet corn dominated the state's canneries. By 1922, 35 of the state's 61 canneries canned sweet corn exclusively. Year Book, 1922, 442. 
Nevertheless, both local promoters and outside investors did succeed in opening canneries in Iowa during a period of great national growth in canning. The number of canneries in the United States more than doubled between 1880 and 1890 from 411 to 1,012, of which 886 were vegetable and fruit canneries. During the 1890s, the canning industry continued to expand although less quickly. By 1900, there were 1,808 vegetable and fruit canneries representing an impressive capitalization of $\$ 27,743,067 .^{24}$ In Iowa, Marshalltown and Vinton saw the establishment of the state's first canneries during the late 1870s. By the turn of the century, when there were 17 canneries in Iowa, the state ranked tenth in the nation in the value of its canned products, with an annual value of $\$ 1,359,958$ placed on its canned goods. (California led the nation, with its canning products valued at $\$ 13,081,829$.) In 1880 there were five Iowa canneries with a total capital of $\$ 66,000$. Five years later, the total amount invested had increased to over $\$ 100,000$. The amount invested in each cannery varied greatly. The Mills County cannery represented $\$ 35,000$ of capital, while the investment in Washington County's facility was only $\$ 4,550$. Regardless of such diverse individual investments, the amount of total capitalization increased dramatically; by 1890, the total capital in Iowa's canneries was $\$ 445,258$. $^{25}$

The individuals who attracted canners or who established a local cannery tended to be from the local elite of Iowa's small towns. The stockholders of the Monticello Canning Company, established in 1904, represented the town's business leaders or

24. Tenth Census of the United States: 1880. Report of Manufacturers (Washington, DC, 1881), 77; Twelfth Census of the United States: 1900. Report on Manufacturers (Washington, DC, 1902), Part 2, 467 and Part 1, 20.

25. Ford, "The Vegetable Canning Industry in Iowa," 6; Eleventh Census of the United States, 1890. Report on Manufacturing Industries, Part 1, 410; Twelfth Census of the United States: 1900. Report on Manufacturing Industries, Part 3, 469, 471; Tenth Census of the United States: 1880. Report of the Manufacturers, 40; Iowa Bureau of Labor Statistics, Biennial Report [for 1885] (Des Moines, 1886), 351, 384, 387. Canneries generally had small capitalization compared to other more prominent industries such as meatpacking. The Eleventh Census of the United States: 1890. Report on Manufacturing, Part 1, 410 and 412, reveals that in 1890 there were 25 wholesale meatpacking factories in the state with a total capitalization of $\$ 4,105,020$; in the same year, the 17 canneries in the state had a sum capitalization of $\$ 445,258$. 
were among the county's most prosperous farmers. They included Jacob Doxee, Andrew Davidson, and Charles M. Hubbell. Doxee graduated from Iowa State College in Ames in 1877; two years later he passed the bar exam and became a lawyer. Besides his legal practice, he owned the Monticello Express, directed Lovell State Bank, and was president of the Monticello Electric Company. He also served for many years on the town's school board. Davidson and his brother together farmed 513 acres. Widely known for breeding some of the region's finest shorthorn cattle, he was a leading member of the Shorthorn Breeders Association and the Clydesdale Breeders Association. Hubbell, one of the area's most successful farmers, owned several hundred acres and invested heavily in real estate. The origins of the Atlantic Cannery also illustrate this pattern. In 1883 J. A. McWaid went into partnership with S. F. Martin and R. D. Wilkins to found a cannery. By 1890, McWaid was the cannery's sole owner. He had demonstrated an intense entrepreneurial spirit almost immediately upon his arrival in Atlantic during the 1860s. He was superintendent of a small meatpacking plant and also owned a 600 -acre farm. In addition, he served as the town's mayor and president of one of the town's leading banks. In 1882 he invested in the town's first creamery. ${ }^{26}$

Canneries were often opened with the assistance of individuals who had gained experience in eastern states. Eastern leadership in the canning industry would continue well into the twentieth century. In 1879 D. W. Archer was instrumental in establishing a factory in Chillicothe, Ohio, and four years later in opening another cannery in Chillicothe, Illinois. The following year he formed a partnership with J. A. McWaid and S. F. Martin, who were part owners of the cannery in Atlantic, Iowa. The three men pooled their resources to open a cannery in Council Bluffs in 1885. Archer then went on to organize Davenport's canning facility. Meanwhile, McWaid and Martin brought in another eastern veteran of the canning trade. In $1889 \mathrm{~J}$. W. Cuykendall, who had extensive experience operating several canning factories in New York State, joined their operation in Atlantic. In 1900

26. R. M. Corbitt, History of Jones County, Iowa: Past and Present (Chicago, 1910), 480, 183, 99, 325; Goldberg and Goldberg, "Atlantic's Canning Season of 1902," 101; History of Cass County (1894; reprint, Lacrosse, WI, 2000), 878. 
he took over the business and helped make the Atlantic cannery one of the most productive and efficient canneries in the state. ${ }^{27}$ Similarly, in Vinton, S. H. Watson hired Henry B. Kelley in 1883 to manage the Vinton canning factory. Kelley had gained the required technical experience by managing a cannery in Lebanon, Ohio. He managed Vinton's facility for eight years until he left in 1891. Kelley's expertise was critical in the cannery's success during its formative years. Prior to his arrival, large quantities of canned goods had spoiled due to poor canning techniques. Kelley contributed to the development of one of the more successful operations in Iowa. In 1903 the secretary of the Benton County Agricultural Society reported that the county "now exceeds all other $[$ sic] in the packing of sweet corn. . . . They also doubled the packing of pumpkin, beans, and tomatoes. ${ }^{28}$

ALTHOUGH both the Atlantic and Vinton facilities canned a variety of products, their operations, like those of the majority of the state's canneries, were dominated by the production of sweet corn. In 1887, for example, the crop represented a majority of the acreage contracted by canning facilities (6,687 acres); the state's other leading canning crops were tomatoes $(1,162$ acres) and peas (220 acres). Sweet corn's dominance continued throughout the industry's formative years. In 1900 the value of canned corn production exceeded one million dollars, with peas, pumpkins, beans, and apples following in that order. By the turn of the century, only New York and Illinois surpassed Iowa in the value of canned sweet corn. ${ }^{29}$

Canners employed a variety of methods to obtain their sweet corn and other crops from Iowa's rich farmlands. They established contracts with farmers prior to the canning season, rented or purchased their own land, and sometimes acquired produce from growers without contracts. In a 1916 study of the sweet corn canning industry in Grimes, Grinnell, and Marshall-

27. Goldberg and Goldberg, "Atlantic's Canning Season of 1902," 101.

28. Arthur I. Judge, ed., A History of the Canning Industry by its Most Prominent Men (Baltimore, 1914), 22; Vinton Eagle, 7/27/1883; Year Book, 1902, 704.

29. Ford, "The Vegetable Canning Industry in Iowa," 9; Report to Governor, 1888, 77; Twelfth Census of the United States: 1900. Report on Manufacturing Industries, Part 3, 477, 479. 


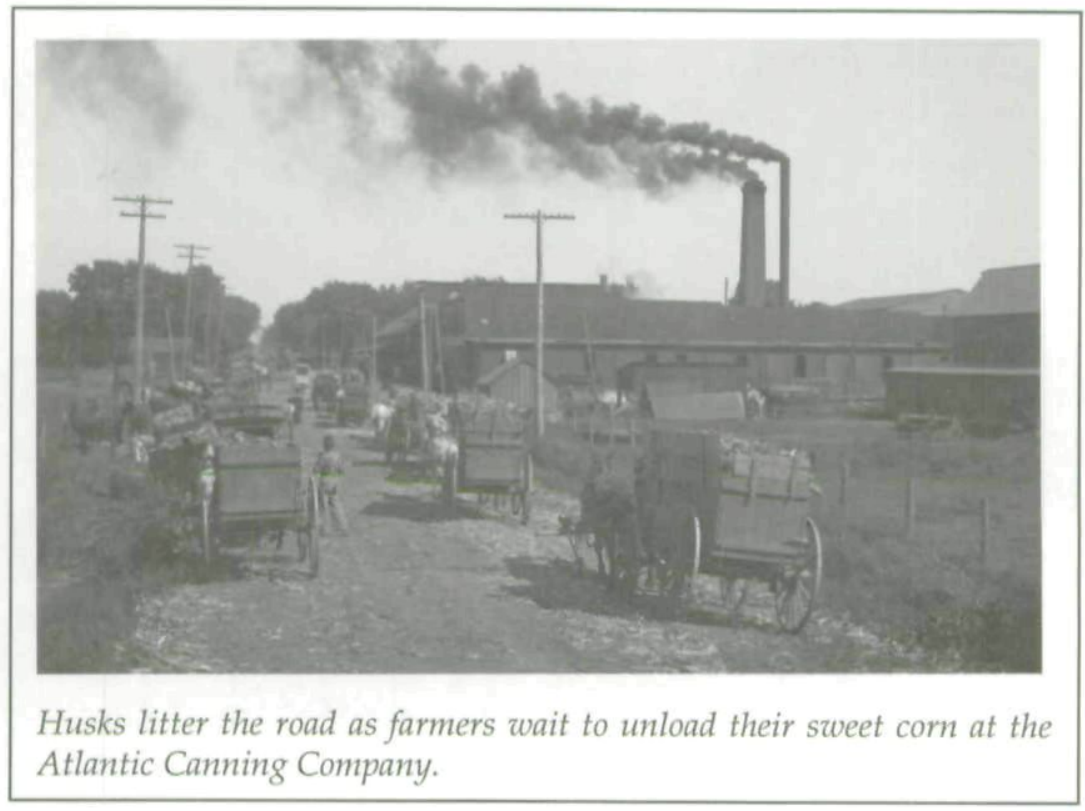

town, M. Glenn Kirkpatrick of Iowa State College found that contracting and company-controlled acreage were the most popular methods. Earl Stewart, an official at the Grimes plant, favored cultivating the sweet corn crop on company or leased property since it decreased dependence on farmers. Other cannery officials, however, favored a mixture of leased and contracted acreage because leased land helped canneries obtain a steady amount of produce throughout the canning season, which was essential to ensure reasonable and efficient work and production rates. Unfortunately, even the best planning did not prevent the problems associated with an uneven flow of produce. "Occasionally too much of the corn ripens together and the amount delivered by each grower per day has to be limited to prevent an excess above what the cannery can handle. This may happen in spite of regulation at planting time, due to conditions of weather." The Atlantic Cannery addressed this problem by encouraging growers to stagger planting. ${ }^{30}$

30. Glenn Kirkpatrick, "A Study of the Sweet Corn Canning Industry at Grimes, Grinnell, and Marshalltown" (master's thesis, lowa State College, 1916), 3, 13. 
During the industry's formative years, canneries also purchased from farmers without contracts. In 1888 John R. Shaffer, secretary of the Iowa State Agricultural Society, indicated that many farmers brought produce to canneries without first obtaining a contract. "It would be impossible to give the number of acres or parts of acres for which no contract was made," he noted, "for in every locality close to a pickling or canning factory there is scarcely a farmer who does not bring wagon load after wagon load of these products, and he never fails to find a ready purchaser." A cannery in Albia, in south central Iowa, often purchased the produce of non-contracted farmers. During both the 1895 and 1896 canning seasons, the local newspaper encouraged non-contracted growers to bring their sweet corn and tomatoes to the cannery. This dependence upon non-contracted farmers might have reflected an experimental phase in the canning industry as Iowa's canners searched for the most effective way to obtain raw materials. ${ }^{31}$

Not all farmers enthusiastically embraced the practice of cultivating canning crops such as sweet corn. Canners had to convince farmers that raising sweet corn or other produce was worthwhile. In 1900 George Franklin, speaking at the 1900 State Farmers' Institute, noted, "It is hard work to get farmers to raise corn for canning factories. The work must be done in hot weather, and the farmers do not like to wait to unload. Sometimes there will be twenty-five or thirty teams waiting to unload and it takes considerable time. ${ }^{\prime 32}$

CANNERS encountered many other problems in their attempts to develop prosperous operations. Like farmers, their success depended on the weather, which often did not cooperate. In 1882 canning operators in Marshalltown and Waukon suffered the effects of an early frost that cut deeply into their earnings by harming delicate crops. In 1886 Keokuk canners experienced a drought that greatly reduced the amount of vegetables they were able to procure from their 600 contracted acres. Harrison Tucker, secretary of the Keokuk County Agricultural Society,

31. ISAS, Report, 1888, 77; Albia Union, 8/6/1896, 8/14/1896.

32. Goldberg and Goldberg, "Atlantic's Canning Season of 1902," 112. 
indicated that canners had "prepared to pack 1,000,000 cans but failed to secure the raw material." Thus their output was reduced to half the expected amount. The same drought crippled the expectations of the Vinton cannery, which had hoped to harvest a record amount of sweet corn. ${ }^{33}$

A number of the state's canneries met their demise due to conflagrations that destroyed both equipment and canning buildings. In 1883 Clinton's cannery suffered a devastating fire. W. H. Schlabach, secretary of the area's agricultural society, emphasized that the fire had caused significant unemployment and forced "shipment elsewhere at a sacrifice of the materials intended for this factory." The following year, a promising beginning of Boonesboro's canning factory came to an end when a fire destroyed that town's facility. The abundance of fire insurance ads in The Canned Goods Trade indicates that fear of the potential for fire to cause overwhelming financial loss was prevalent among canners. Companies such as the Canners' Exchange Company in Chicago advertised regularly to entice canners to purchase insurance to protect themselves against the threat of fire. ${ }^{34}$

The experience of the Albia cannery demonstrates how both nature and the technical aspects of canning presented a host of challenges. In 1894 the Albia Canning Company was capitalized at $\$ 21,000$, an average amount for the time, and obtained an excellent location adjacent to the Chicago, Burlington, and Quincy railroad track. The following year, cannery officials initiated operations. The first season proved disappointing due to a host of problems, including maladjusted machinery and insufficient piping for water. Workers were still involved in maintenance and preparation work in August. Carpenters were making boxes for corn cobs, and well diggers were sinking wells to provide water for the facility. In addition, the management had failed to order enough tin cans, which greatly slowed produc-

33. ISAS, Report, 1883, 521, 326; ibid., 1887, 453; Vinton Eagle, 8/3/1886. The time of Iowa's first frost varied greatly between 1890 and 1920. For instance, in Vinton, the location of the Iowa Canning Company, the earliest recorded frost arrived on September 12, 1902; the latest occurred on November 2 in 1924, 1926, and 1931. Ford, "The Vegetable Canning Industry in Iowa," 17.

34. ISAS, Report, 1883, 379; ibid., 1884, 341; Goldberg and Goldberg, "Atlantic's Canning Season of 1902," 112; The Canned Goods Trade, 7/12/1912, 21. 
tion. A Union writer stated that "the canning factory was closed down on Saturday on account of having filled the cans for corn that had been bought, a car load of cans from the Gilman factory was discovered at Maxon, a railroad junction east of Albia, and President Cramer set the telegraph wires in motion, and got consent to take out 3,000 cans." This situation reveals the challenge of coordinating available workers, supplies, and raw materials into a smooth and systematic manufacturing process. ${ }^{35}$

Despite these and other problems, the town's press remained supportive. The paper continued its positive appraisal and remained confident in the plant manager's abilities. A. A. Mason, editor of the Albia Union, wrote, "Under his management the factory will be prosperous if it can be made profitable by anybody. ${ }^{\prime \prime 36}$ When rumors circulated in Albia that sanitary conditions at the facility were poor, the Union reported that a tour of the plant by the town's prominent citizens proved "there isn't a cleaner or nicer kitchen in Iowa.. ${ }^{\prime 37}$ Unfortunately, mishaps continued. A large amount of the first season's canned corn spoiled soon after processing. Misjudgments regarding the proper price that should be paid to farmers for their crop further complicated the matter. As a result of these various misfortunes and mistakes, the company operated at a net loss of $\$ 2,000$ for its initial summer of operation. Consequently, new owners purchased the factory and placed it under new management. Nevertheless, the Albia cannery survived its first unsuccessful season and began to prosper under new management. ${ }^{38}$

The experience of the Albia cannery illustrates the challenges in establishing a successful cannery. An Iowa cannery could be doomed by any of many misjudgments or uncontrollable circumstances. Crucial conditions included the time of harvest, the right price for raw produce, proper location, and

35. Frank Hickenlooper, An Illustrated History of Monroe County, Iowa (1896; reprint, Marceline, MO, 1976), 295; Albia Union, 8/2/1895, 9/3/1895.

36. Albia Union, $8 / 2 / 1895$. Although the paper was optimistic concerning the abilities of cannery officials, it does not provide any evidence of the level of experience these managers possessed. If they were not highly experienced canners, this may explain the numerous difficulties of the Albia facility.

37. Ibid., 8/20/1895.

38. Hickenlooper, Illustrated History of Monroe County, 295. 
sufficient capital. Canners also had to convince area farmers to enter into contracts with them. This sometimes proved difficult because some crops such as sweet corn had to be harvested during some of Iowa's hottest weather. Thus, the period witnessed the establishment and demise of a large number of canneries throughout the state, many of which did not survive for long. ${ }^{39}$

There were also issues of quality, which troubled even the state's most successful canners. This problem surfaced early in the history of the state's canning industry and reflected a national concern pertaining to the possible health dangers associated with canned goods. The secretary of the state agricultural society reported in 1881 that some of the initial canning operations had not succeeded because some of the product delivered to customers had been of inferior quality. The earlier high demand for canned goods, he wrote, had slipped because some canners had "put up inferior articles, and that which promised only a few years ago to be one of the very surest methods of disposing of our surplus, has been tainted with the gravest suspicions. ${ }^{\prime 40}$ Cannery owners were tempted to add a range of substances to artificially enhance the appearance or flavor of canned items that were originally of inferior quality, but the practice of adding adulterations hurt the reputation of the state's canned goods. Cannery official Walter Eliott, writing in 1900, emphasized that "all these things are wrong from a health point of view, and in the light of honest dealing, one with another. Our business can never be firmly established and built up until these practices are eradicated. The using of acids and bleaching preparations, that are often used, destroy the real food qualities and injures health, are an abomination and dishonest." He urged legislators to intervene by enacting a pure food law to remedy the situation. He also advocated incorporating scientific methods to continually monitor the quality of the state's canned goods. ${ }^{41}$

During the first decade of the twentieth century, attempts to improve both the quality and safety of canned goods accelerated. The passage of the federal Pure Food and Drug Act in 1906

39. Year Book, 1900, 22.

40. ISAS, Report, 1881, 30.

41. Year Book, 1900, 20. 
reflected the nation's growing demand for safer foods. The National Canners Association (NCA) encouraged canners to improve the quality of their products; the organization also established a publicity branch to investigate accusations of food poisoning from canned goods. In Iowa, this included a number of situations involving accusations in which tainted corn, salmon, oysters, or other items had been blamed for injury or even death. NCA investigators sometimes discovered that the poisoning was a result of improper food handling after opening. For example, one individual residing in western Iowa consumed a portion of canned salmon after it had been opened for a few days. The NCA also threatened local journalists with legal action to pressure them into retracting articles in which there was insufficient proof of food poisoning. Nevertheless, there were cases in which food items clearly had been adulterated. In 1910 the U.S. Attorney for the Southern District of Iowa, acting on behalf of the U.S. Secretary of Agriculture, discovered that a southern Iowa food processing facility had produced adulterated ketchup that contained dangerous levels of bacteria and excessive levels of a preservative agent. Government inspectors fined the owner of the facility $\$ 200$, but the amount was later reduced to just $\$ 40$. Regional canning associations, such as the Iowa Canners Association and later the Iowa-Nebraska Canners Association, worked in cooperation with the NCA to increase the quality of canned goods. Nevertheless, problems persisted. According to a 1922 report, most canneries were employing proper sanitary methods; however, a few were not disposing of vegetable waste or cleaning equipment in the appropriate manner. ${ }^{42}$

WHILE MANAGERS faced their share of problems in establishing prosperous operations, workers endured their own set

42. The Canned Goods Trade, 2/2/1912, 32; ibid., 2/24/1911, 40-43; ibid., 9/15/ 1911, 12; Year Book, 1922, 439. It is difficult to determine an exact date for the establishment of a state canning association; however, articles in The Canned Goods Trade pertaining to the activities of the Iowa Canners Association were appearing regularly as early as 1910 . The organization met annually to develop solutions to the problems of the state's canning industry and garnered widespread membership among the state's canners. For some brief but useful articles, see The Canned Goods Trade, 11/18/1910, 19; ibid., 10/27/1911, 20; ibid., $11 / 17 / 1911,6$. 
of challenges as they labored in the canneries. Cannery workers endured poor working conditions, such as exposure to the noise of loud equipment and the heat that the cookers added to the already high summer temperatures. They often developed skin rashes from continuously handling moist vegetables. Although serious accidents, such as steam cooker explosions were rare, they did occur. Iowa canneries were also characterized by brief but intense work seasons, gender-segregated work roles, and large amounts of child labor during the industry's early period. In 1900 Iowa canneries employed 606 people in August and 1,722 in September during the peak of the harvest season. October and November represented the next highest employment numbers, with 395 and 259 employees respectively. The Iowa Bureau of Labor Statistics reported that in 1895 on average Iowa's canneries were working "full time and full force" six weeks out of the year; in 1896, it was five weeks out of the year. This relatively short canning season was typical of Iowa canneries throughout the period. ${ }^{43}$

Short work seasons resulted in relatively long work days in comparison to other industries. There is little evidence from the nineteenth century, but early twentieth-century descriptions and an understanding of the perishable nature of raw materials suggest that canning involved long days in both centuries. In the early 1920s, Monnie Stauffer labored in a Marshalltown cannery; as a girl of 15, she could work whenever she wanted any day of the week with a shift usually between 10 and 15 hours per day. However, when the management found out that she was under 16, they limited her to eight hours because of child labor laws. In the early 1930s, Earle Ferguson worked at the Vinton canning factory after graduating from high school. During the pea harvesting season the factory operated 24 hours per day. In one week Ferguson worked 118 hours for \$39. The long hours in the state's canning facilities lasted at least until World War II. During the peak seasons of the early 1940s, Joy Stender

43. Lotys Benning, The Vegetable Canning Industry (Indianapolis, 1938), 35-36. For a description of a boiler explosion, see the Vinton Eagle, 9/9/1904. Twelfth Census of the United States: 1900. Report on Manufacturing Industries, Part 3, 483; Iowa Bureau of Labor Statistics, Biennial Report, 1895-96, 55 (hereafter cited as IBLS, Report). 
usually worked an 18-hour day, seven days per week, at Muscatine's Heinz plant. On one occasion she worked 26 hours in one shift with no bonus for her extra time. Glenn Richardson had worked in the same plant in the early 1920s. He lived on a farm west of town, but in August and September, during the peak canning season, he worked in town. His recollections confirm the seasonal nature of the work. He indicated that the Heinz plant hired up to 1,000 extra workers between July and October, but only 250 to 300 during the rest of the year. It "was real hard work," he recalled, "but we had a good boss." ${ }^{44}$

Canneries, in comparison to most other industries, employed large numbers of women and significant numbers of children. For instance, the 1880 census indicated that out of a total of 118 workers in the state's five canneries, 70 (59 percent of the total workforce) were women over 15 years of age. In 1885 Iowa's Bureau of Labor Statistics reported that 43 percent of the labor force were women, 30 percent were children, and 27 percent were male. Thus, 73 percent of the workforce were either women or children. The portion of children in the canneries' workforce declined in the remaining years of the century, while the portion of women remained steady. ${ }^{45}$

The large number of children in Iowa's canneries was part of a national pattern, especially in rural canneries. Mechanical devices were adopted more slowly in rural canneries than in their urban counterparts, which usually processed a greater

44. Monnie Stauffer, interview by Greg Zieren, 3/6/1980, Iowa Labor History Oral Project, Iowa Federation of Labor, AFL-CIO, State Historical Society of Iowa, Iowa City; Earle Ferguson, interview by Greg Zieren, 10/24/1980, ibid.; Joy Stender, interview by Greg Zieren, 7/25/1980, ibid; Glenn Richardson, interview by Greg Zieren, 7/25/1980, ibid.

45. Tenth Census of the United States: 1880. Report of the Manufactures, 40; IBLS, Report, 1884-85, 351. In 1890 the industry employed 1,637 people during the peak season, 124 of which (7.6 percent of the total workforce) were children. Eleventh Census of the United States: 1890. Report on Manufacturing Industries, Part 1, 199. In 1900, in a total workforce of 699 people, there were 112 children (16 percent of the workforce) and 266 women (42 percent). Twelfth Census of the United States: 1900. Census Manufacturers, Part 3, 470. In 1910 women represented 15.5 percent of the labor force for all manufacturing and mechanical industries. Schwieder, Middle Land, 249. In some Iowa industries, such as meatpacking, women were largely absent from the workforce until 1905. See Warren, "Evangelical Paternalism and Divided Workers," 335. 
number of crops and worked for a longer season. Many of Iowa's canneries existed in small communities and depended almost completely on sweet corn for their profits. The rate of mechanization also varied according to the manufacturing stage. The cook rooms, which processed the cans themselves, incorporated technological innovations quickly, while preparation rooms, where the vegetables were processed, were slower to automate. Children were a ready source of labor in these unskilled aspects of the canning process. ${ }^{46}$

As states passed legislation restricting child labor in the early years of the twentieth century, the number of children employed in canneries nationally decreased from 18 percent to 3 percent between 1879 and 1919. Iowa's canneries followed the national pattern. In 1885, 27 percent of Iowa's canning labor force was children, much higher than the 18 percent nationally in 1879. Children continued to be present during the first years of the twentieth century. The labor force at Atlantic's cannery included 6 percent children in 1902 and 5 percent in 1905 and 1906. The Jones County cannery had larger numbers of children engaged in cannery work in the early years of the twentieth century ( 23 to 24 percent in August and September 1905). ${ }^{47}$

Concerned about the effects of children working long hours in canneries and other factories, successive commissioners of the Iowa Bureau of Labor Statistics joined women's clubs and other activists in the early twentieth century in calling for legislation to restrict child labor. When the General Assembly passed such legislation, it added new responsibilities to the duties of the bureau's factory inspectors, who gradually succeeded in reducing the number of children in the labor force. By 1909, for example, both the Jones County and Atlantic canneries reported no children in their employ. ${ }^{48}$

46. Martin Brown, Peter Phillips, and Jens Christiansen, "The Decline of Child Labor in the US Fruit and Vegetable Canning Industry: Law or Economics?" Business History Review 66 (1992), 725.

47. Brown et al., "The Decline of Child Labor," 724; IBLS, Report 1884-85, 351; ibid., 1901-02, 399; ibid., 1905, 262; ibid., 1906-07, 343, ibid., 1909-10, 444, ibid., 1905, 264 and 266; ibid., 1908-09, 444; ibid., 1906-07, 346.

48. IBLS, Report, 1899-1900, 20-22; ibid., 1901-02, 5; ibid., 1905, 5-8; ibid., 190607, 6-7; ibid., 1908-09, 7-8; Laws of Iowa, 1906, 71-73; John E. Briggs, History of Social Legislation in Iowa (Iowa City, 1915), 13-14, 278-80. 
The nature of labor in Iowa's canneries also revealed the gap between women's and men's wages. Iowa canners divided job duties into "women's work" and "men's work." During the late nineteenth century, female cannery workers were usually relegated to lower-skilled and lower-paying jobs. The management prohibited women from taking on skilled tasks such as capping the filled cans or working in the cook rooms. Instead, women completed preparation tasks where they prepared vegetables and placed them in cans. The containers were then sealed by skilled cappers, often specialized tinsmiths. The jobs most often dominated by women included scalders, peelers, and packers, who were in some instances paid half as much as cappers and cookers, who were generally men. ${ }^{49}$

Iowa's canneries reflected this national disparity in wages and divisions of labor. The earliest statistics indicate that canneries usually paid women significantly less than their male counterparts. In 1885 the Iowa Bureau of Labor Statistics indicated that women averaged $\$ 87$ per season in canneries, while men averaged $\$ 110$ per season. The highest wage for a man was $\$ 3$ per day while women could make $\$ 2$. The lowest wage for a woman was $40 \notin$ per day; men bottomed out at \$1.04. In June 1902, an article in the Atlantic Messenger describing the town's pea canning season illustrated how gender operated in the workplace. The writer indicated that women were usually responsible for examining the produce and removing the peas

49. Martin Brown and Peter Phillips, "Craft Labor and Mechanization in Nineteenth American Canning," Journal of Economic History 3 (1986), 744, 746. For treatments of the prevalence of gender segregation in California canneries, see Vicki L. Ruiz, Mexican Women, Unionization, and the California Food Processing Industry, 1930-1950 (Albuquerque, NM, 1987); and Elizabeth Reis, "Cannery Row: The AFL, IWW and Bay Area Italian Cannery Workers," California History 34 (1985). Such differences in compensation based on gender were typical in late nineteenth- and early twentieth-century workplaces. Wilson Warren discovered this notion of "women's work" in his investigation of the John Morrell meatpacking plant in Ottumwa. During the early twentieth century, female employees at Morrell were primarily "labelers," "sausage makers," and "meat trimmers." Warren, "Evangelical Paternalism and Divided Workers," 335; and idem, "Welfare Capitalism of John Morrell and Company," 502. Cf. Bruce Fehn, "'Chickens Come Home to Roost': Industrial Restructuring, Seniority, and Gender Conflict in the United Packinghouse Workers of America," Labor History 34 (1993), 324-39; Dennis A. Deslippe, "Rights, Not Roses": Unions and the Rise of Working-Class Feminism, 1945-80 (Urbana and Chicago, 2000). 


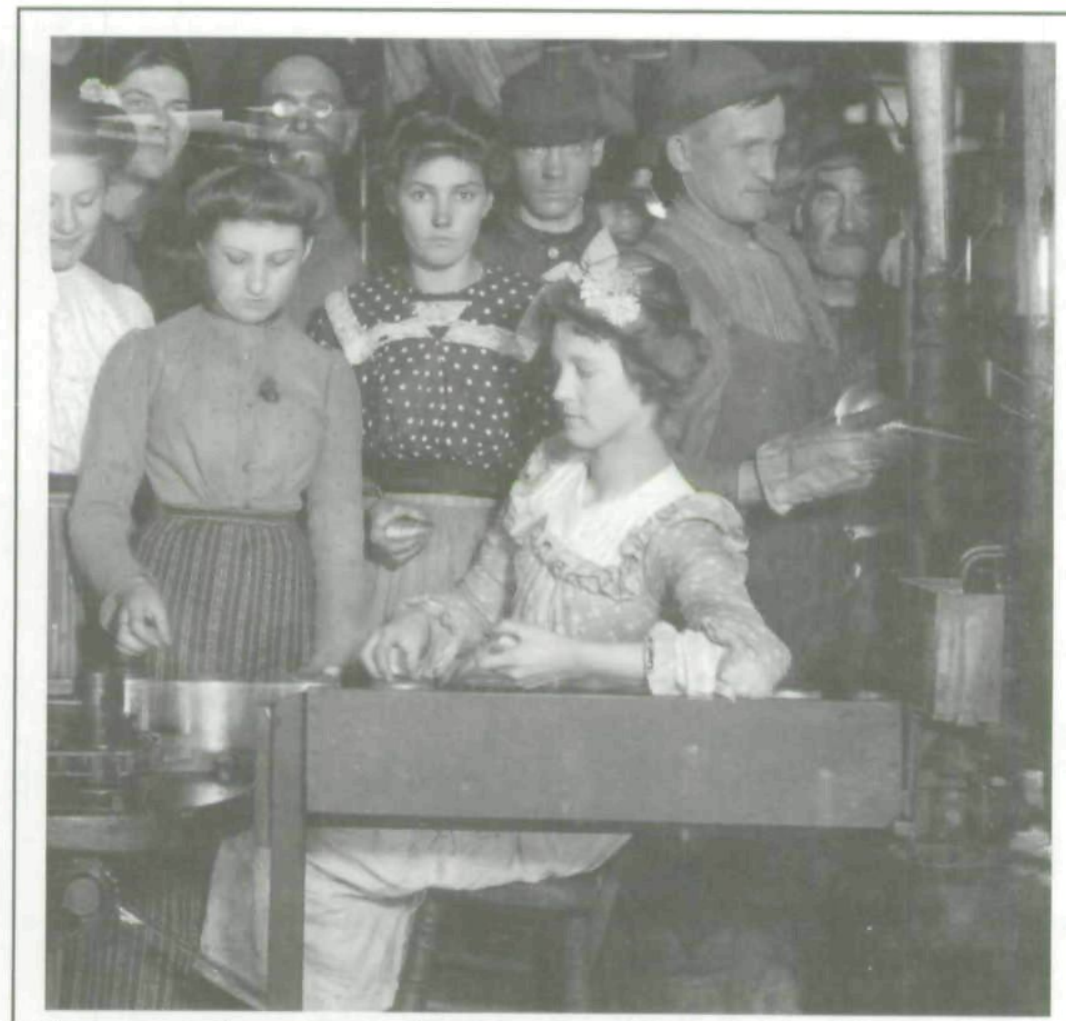

Women workers were assigned to place lids on cans, while men (opposite) soldered the lids onto the cans.

that were not up to quality standards; they also placed the lids on the cans. Soldering the lids onto the cans was considered a man's job. In August 1895 another of the town's papers, the Atlantic Telegraph, stated that a "small army of women and girls" were feeding the cutting machines and placing the lids on the cans before the cans were soldered. In 1908 an article that first appeared in Wallaces' Farmer indicated that at the Grimes plant "the husking is mostly done by women and children, who receive three cents a bushel for the work." ${ }^{150}$

50. IBLS, Report, 1884-85, 351; Goldberg and Goldberg, "Atlantic's Canning Season of 1902," 103; Atlantic Telegraph, 8/21/1895; Year Book, 1908, 659 (quoting Wallaces' Farmer). Women's wages in canneries compared favorably to the nine other industries for which women's salaries were listed in the report. Canning, along with three other industries ("Machine Shops, Foundries and 


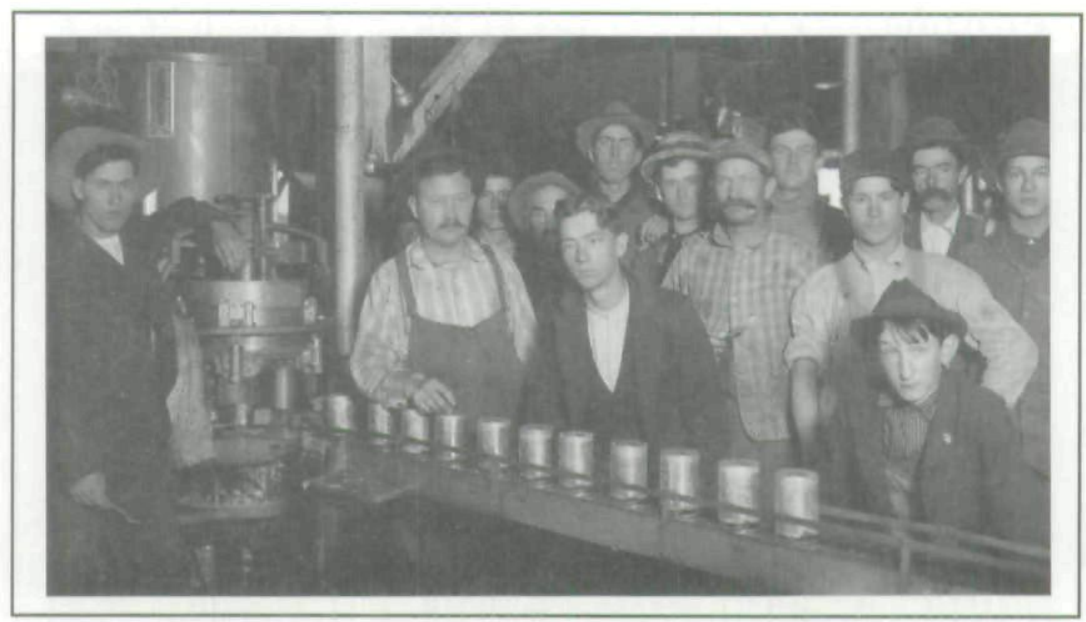

The division of labor in Iowa's canneries appears to have persisted throughout the era and across the region. When asked if there was a division of labor at Muscatine's Heinz plant in the 1930s, Glenn Richardson stated, "Oh, yes. At that time, you know, there was women's jobs and men's jobs," and "women had to work harder." Women tended to work in jobs such as placing cans and bottles in cases, sorting out the bad produce, peeling onions, and cleaning up. Richardson also indicated that there were few women supervisors and no female mechanics. Nevertheless, he believed that most of the women looked forward to the money since many of them were homemakers who rarely worked outside the home. Joy Stender justified the women's willingness to work for low wages, stating that "for the price we got to work all the hours we could work to lay up a little coal and stuff for the winter." During hard times this extra money could make a big difference. The money women made during the canning season made it possible for families to "have a few extras so that we could live through the winter. That's the way it was. You either done that or you starved, that's all there was to it. ${ }^{\prime 51}$

Boiler Shops, and Wagons and Carriages, Harness") paid the highest wage of $\$ 2$ per day. The canning industry's lowest wage of $40 \notin$ per day was lower than five of the nine industries reported. IBLS, Report, 1884-85, 351.

51. Richardson interview; Stender interview. 
The fact that men generally held positions of authority within the canning industry may have had unfavorable consequences besides a disparity in wages. Although there is little evidence revealing the level of sexual harassment in Iowa's canneries, such behavior did occur in other midwestern canneries. In 1911 Rosa M. Perdue, a young female worker in Wisconsin, stated that while working at the cannery "All 'de guys' came to flirt with the girls. As our arms were bare to the elbows they handled us as they pleased, caught us by the hands and insisted on promises that they be permitted to see them home after work. Several of the girls swore at the men but usually received the more attention for their protests. ${ }^{152}$

DESPITE such challenging working conditions, Iowa's communities welcomed canneries. In 1879 Vinton's J. W. Rich, a member of the Benton County Agricultural Society, praised the accomplishments of the S. H. Watson Canning Company's first year, when it had produced 600,000 cans. The company also improved its facilities by adding two new buildings in the hope of increasing its production to one million cans. The following year, T. B. Cobbey, another member of the area's agricultural society, cited the factory's contributions of employing approximately 300 people during the peak season and paying the workers from fifty cents to three dollars per day. By 1888, when the company processed more than 1.6 million cans of corn during that year's canning season, a Vinton Eagle writer stated, "Monday was payday and $\$ 3,000$ was paid out for labor alone, and $\$ 5,000$ is being paid out per week for corn." This was an important source of supplemental income for the area's farmers. F. D. Simpson, who worked in the cannery as a young man, recalled that "for many years the plant was a source of seasonal income for area farmers with whom the factory would contract each year for sweet corn." The surrounding communities also recognized the benefits of canneries. Belle Plaine, a town in the southwestern portion of the county, had acquired a cannery by 1883 , and Garrison, approximately ten miles west of Vinton, had one by 1899. Benton County would become one of Iowa's leading

52. The Canned Goods Trade, 8/4/1911, 12. 
counties in sweet corn canning. In 1903, the county's total production was ten million cans. ${ }^{53}$

In the southwestern portion of the state, W. B. Temple, secretary of the Cass County Agricultural Society, noted that the Atlantic Cannery had been of great advantage to that area's farmers. After the establishment of the facility in 1882, the factory increased production steadily throughout the 1880s: workers canned 250,000 cans of corn in $1884 ; 450,000$ in $1885 ; 800,000$ in 1886; one million in 1887; and almost two million in $1887^{54}$

During the 1880s and 1890s, town leaders throughout Iowa made similar comments about many other canneries, revealing other less apparent benefits. In 1895 the Albia Union noted that its cannery provided feed for livestock as the canner gave husks and cobs to farmers who brought their produce to the factory. "The husks make good cow feed, fellows," the paper crowed, "and if you have a canning factory near you it will pay to haul out an occasional load. Try it and see." The canning industry's national press also recognized the benefit of using sweet corn waste for livestock. In 1911 M. L. Nelson, a writer for The Canned Goods Trade, boasted of the high nutritional value of cornstalks as livestock feed and encouraged farmers to take advantage of this beneficial feed source. ${ }^{55}$

PARTICIPANTS in the expansion of canneries as well as local boosters pointed to the canning industry's numerous advantages, but they failed to acknowledge the industry's social costs, reflected particularly in working conditions for women and children. Nevertheless, Iowa canneries often did fulfill the hope of providing benefits to both farmers and local townspeople. Although their contributions were not as significant as larger

53. ISAS, Report, 1880, 274; ibid., 1881, 35; Vinton Eagle, 9/4/1888; ISAS, Report, 1889, 298; F. D. Simpson, Atlantic, Iowa: One Hundred Years of Pioneering and Progress, 1868-1968 (Atlantic, 1968), 50; Year Book, 1902, 704; ISAS, Report, 1884, 335; ibid., 260; Year Book, 1904, 727.

54. History of Cass County, 180; ISAS, Report, 1884, 350; ibid., 1885, 302; ibid., 1886, 290; ibid., 1887, 307; ibid., 1888, 295.

55. Albia Union, 8/13/1895, 8/16/1895; The Canned Goods Trade, 3/3/1911, 32-35. J. A. Cuykendall of the Atlantic Cannery used "refuse corn" to feed his extensive livestock holdings. Atlantic Telegraph, 8/8/1901. 
industries such as meatpacking, the canning industry's economic advantages included additional jobs and alternative crops for Iowa farmers. ${ }^{56}$

More objective observers also affirmed the importance of the expansion of agricultural industries. In 1939 Deane W. Malott at the Harvard School of Business and Boyce F. Martin, a Harvard instructor in agricultural industries, indicated that "the development of agricultural industries has provided an outlet for farm products. These industries have become the funnel through which the consumers' dollars flow through the farm. ${ }^{157}$ Iowa's town leaders encouraged the establishment of canneries as they did other food processing industries, believing that such ventures resulted in greater prosperity. Although the number of Iowa canneries would greatly diminish following World War II, the quest to find additional uses for corn continues to evolve, as shown by the emergence of the corn refining industry. ${ }^{58}$

56. The Canned Goods Trade, 11/17/1911, 6 .

57. Deane W. Malott and Boyce Ficklen Martin, The Agricultural Industries (New York, 1939), 2.

58. For a useful discussion of the problems the state canneries encountered during the 1930s and 1940s, see Ford, "The Vegetable Canning Industry in Iowa." Ford argues that the small scale of many of the state's canneries made them vulnerable to challenges that intensified during the 1940 s. These problems included difficulties convincing farmers to cultivate sweet corn, troubles obtaining adequate labor, and competition from emerging sweet corn growing regions in the Northwest and elsewhere. Frozen vegetables were also beginning to appear in the marketplace in increasing numbers, and most Iowa canneries were not willing to adopt freezing operations. The amount of frozen corn produced nationally increased dramatically from 200,000 pounds in 1932 to 62.7 million pounds twenty years later. See Robert A. Huelsen, Sweet Corn (New York, 1954), 382. For a brief discussion of the origins and early development of the frozen foods industry industry, see R. W. D. Macintosh, Frozen Foods: The Growth of an Industry (London, 1962). For an exhaustive discussion of the industry's early decades as well as many useful statistical tables relating to its growing share of the market, see Donald K. Tressler and Clifford E. Evers, The Freezing Preservation of Foods (New York, 1947). In 1990 Paul E. Gunder, chairman of the Corn Refiners Association (CRA), reported that "competitive pressures in the corn refining industry have for many decades spurred efficiency and technological innovation." His comments reflect the prevalence by the late twentieth century of an ever-expanding use of corn derivatives, such as corn starch, corn syrups, and oils which were increasingly being incorporated into a variety of consumer products. A 1989 study conducted by the CRA listed "3,799 different uses of refined products," representing dramatic growth from the early 1960s. Corn Annual, 1990, 4, 7. 
The canning industry's development reflects the reality that the optimism that characterized Iowa's small towns during this period was repeatedly tempered. Town leaders celebrated their canneries' rising production levels and increasing payrolls, but launching and maintaining a successful venture entailed many obstacles. Canneries required adequate technical knowledge, a stable supply of raw material, and a quality product. Iowa's canners also faced a host of challenges beyond their control, such as destruction by fire, poor weather conditions, and the emergence of new sweet corn growing regions. The Albia cannery's marginal performance and the disappearance of many other canneries reveal that the hopes of many town boosters were dashed. Yet the history of the state's canning industry demonstrates Iowans' great optimism and adaptability in facing the period's economic challenges. As they developed canneries, Iowans also expressed their gender conceptions, contributed to the expansion of options for the nation's consumers, and increasingly connected themselves to a national marketplace. 
Copyright of Annals of Iowa is the property of State of Iowa, by \& through the State Historical Society of Iowa and its content may not be copied or emailed to multiple sites or posted to a listserv without the copyright holder's express written permission. However, users may print, download, or email articles for individual use. 